\title{
THE PROCESS OF AUDITING PROJECTS BY THE REVIEW OF ITS CRITICAL SUCCESS FACTORS
}

\author{
R McDonald, Siemens
}

\begin{abstract}
In spite of the fact that benefits from successful project implementation can be achieved by governance over the formal controls and project practices, there is still evidence of high project failure rates across a broad range of industries. It is all too often found that significant effort and emphasis is placed on reviewing the project from the project managers' perspective (with the emphasis on financial and technical aspects), and that independent parties do not perform formal controls. It is understood that an independent project audit would result in an objective report and that all parties involved may not necessarily share the same view.
\end{abstract}

A proposed approach is to have project audits carried out by reviewing the implementation of critical success factors against accepted project standards. These results are tabulated in a matrix that allows for the documentation of success factor implementation and opens up the possibility for scoring the extent of the implementation.

This article adds to recent research done in an effort to identify critical success factors and identify new methods for determining them, while focusing on the concept of project audit.

Keywords: project audit; project control; post project review

\section{INTRODUCTION}

The word "audit" is normally not taken lightly, even by the most experienced professional, and the "auditing of projects" should also be taken seriously. This article explains what is meant by "an audit" and more so, how a project audit may be executed by the review of its success factors. While project management aims towards professional status recognition and the international implementation of profession regulation, much work still needs to be done to secure an identification of best practice methods and controls. Project auditing proposed by this article is another step towards methods of review and control and further adds professionalism to the review and correction process.

The root of the word audit is to be found in the Latin auditus (noun), as an act of hearing, and is defined as a methodical examination and review (Merriam-Webster, 2004). Traditional definitions, as in Websters New World Dictionary (1977:37), define an audit as a formal, often periodic, examination and checking of accounts or financial records to verify correctness. Encyclopaedia Britannica (2004) define the word audit as the examination of the records and reports of an enterprise by accounting specialists other than those responsible for their preparation. As seen in these descriptions, the process of auditing and the main use of the word "audit" have typically been used in conjunction with the practice of financial accounting.

A project is defined by PMBOK (2000:4) as a temporary endeavor undertaken to create a unique product or service. Temporary means that every project has a definite beginning and a definite end. Unique means that the product or service is different in some distinguishing way from all other products or services.

There is no universally accepted definition for the term "project audit." Following traditional definitions, Williams (1977:9) defines an engineering audit from the American institute of Industrial Engineers as an official periodic examination and verification of accounts and records concerned with the design, improvements, and installation of integrated systems of men, materials and equipment in an organisation. Williams (1977:10) resolved to answer questions such as the following: What is an audit? Why have an audit? What should it include? When should an audit be done? What would be the audit procedure? 
I would propose that a project audit could be defined as follows:

An independent examination of records and activities to ensure compliance with established controls, policy and operational procedures, as well as to recommend any indicated changes in controls, policy and procedures, with the view to verifying that the correct procedures and controls are in place in order to secure the most favourable outcome for the project.

As a result, a project could be audited for (but not limited to) the following aspects:

- the cost control systems for a particular project

- the processes governing quality control

- the procedures used related to scheduling

- methods used for the management and compliance of scope control

- confirmation of the correct use of variation adjustments

- compliance with the legalities of an associated contract

Project audits, and not mere post mortems or clinical reviews, are needed to adjust the direction of a potentially failing project.

As previously indicated, project auditing proposed by this article adds another step towards methods of review and control of projects. The purpose of this article is to describe a process of auditing projects, by reviewing its success factors against established controls. Further objectives of this article will be to explore the possibility of scoring the extent of the implementation of success factor control mechanisms.

The concept of the audit must be to review, measure and propose corrective action where necessary. If a process of review against established controls is not followed, the authenticity and validity of the audit will be brought into question. Further, if no method of measurement is introduced, then ranking a project within its industry will be a difficult process.

\section{HOW PROJECTS ARE EXAMINED}

Projects have traditionally been examined for performance by only a handful of interventions. Three such interventions that are commonly used include:

- project review meetings

- project status meetings

- $\quad$ project post mortems or post project reviews

These three will briefly be introduced.

\section{Project review meetings}

Kerzner (1998:277) indicates that project review meetings are necessary to convince key personnel that orderly progress is being made on a project. He indicates that there are three main types of review meetings, described as follows:

- project team review meetings

- executive management review meetings

- customer project review meetings

Often projects teams have weekly, twice a month, or monthly meetings in order to keep the project manager and the project team informed about the project's status. These meetings are flexible and should be called only if positive benefits will result. Meetings should not be called just for the sake of having meetings. Having either too many or too few meetings can prove detrimental. 
Executive management has the right to require monthly status review meetings. However, if the project manager believes that other meeting dates are better (because they occur at a point where progress can be identified), then he should request changes in date from top management.

Customer review meetings are often the most critical and most inflexibly scheduled. Every attempt must be made to adhere to the requirements for such meetings. Project managers often overlook the fact that their project is simply one of several interrelated projects for the customer. Project managers must allow time to prepare handouts and literature well in advance of the meeting. This preparation and/or travel time must be accounted for in the budget.

Project review meetings have the character of looking back on what was achieved on the project.

\section{Project status meetings}

Project status meetings are typically focused on the current status of the project in relation to its expectations. Project status meetings are management meetings where project related management decisions are made, concerning planning and controlling the results of the project (Siemens, 1994:39).

\section{Post project reviews}

Post project reviews are review meetings that take place after the completion of the project. Their principle aim is for the project team to gain learning from their experiences and avoid making the same mistakes on future projects.

In an assessment of post-implementation project reviews, Busby (1999:23) found that post project reviews are effective in disseminating knowledge about good practices, correcting errors in individual's knowledge, and predicting how well alternative practices would have turned out. In support of this view, DeFillippi (2001:6) indicates that there is a growing body of evidence of enormous benefits to organisations that incorporate reflective practices, like post project reviews, into their project management processes.

Von Zeidtwitz (2002:255) also conducted research over a four-year period and found that postimplementation reviews create an opportunity to systematically improve performance in subsequent projects. However, a survey reveals that only one out of five projects receives a post project review. Post project reviews, if they take place, are typically constrained by lack of time and attention as well as lack of personal interest and ability.

\section{PROJECT GOVERNANCE}

In an attempt to improve the success rate of projects, project governance is receiving increasing attention from both academics and practitioners (Turner \& Keegan, 2001:613). Inadequate governing of projects, or no governance, could lead to unsuccessful project outcomes. The Central Artery/Tunnel (CA/T) Project in Boston, also known as the Big Dig Project, and the Fast Ferry Project in Canada, are cited by Liu (2004:2) as being typical cases in point.

- $\quad$ The Big Dig Project is the largest federally funded public works project in recent United States (US) history. With an initial cost estimate of US\$2.4 billion in 1984, the cost ballooned to US\$13.6 billion by 2000 and US $\$ 14.6$ billion in 2002. A federal task force conducted a review on project cost and oversight in early 2000 and identified, among others factors, a lack of governance as a main reason for cost overruns (FHA, 2002; Murphy, 2000).

- The provincial government of British Columbia, Canada, in 1994 announced the Fast Ferry Project, to construct three fast car ferries for the British Columbia Ferry Corporation. The total cost for the project had risen from the original estimate of $C \$ 210$ million to an estimated $C \$ 463$ million. An audit conducted by the Office of the Auditor General of British Columbia has 
concluded that poor project governance is the main reason for cost overruns and delays (Morfitt, 1999).

One of the most commonly used governance mechanisms for senior managers' active involvement in a project is a project sponsor. Since senior management's time and attention to projects is limited, senior management is unable to be involved in all aspects of project operations. Typically, the project sponsor is someone who is high in an organisation's hierarchy, the owner of the business case for the project, and is responsible for making sure the conduct of the project is in the best interests of the organisation and stakeholders (Kerzner, 2000:237-249).

The literature recommends management support as a universal approach to successful projects without addressing the contingent effect of this management support (Sabherwal \& King, 1992:917-943). Thus, the normative question is: "Under what conditions should management proactively involve themselves in the project management decision process?"

In addition to direct intervention by senior managers, project organisations can govern projects through project reviews and steering committees; organisations can also govern projects by establishing project offices. Existing studies on the effects of project reviews and project offices are mostly conceptual and it is proposed that projects should be audited by reviewing the extent of the use of its identified success factors.

\section{ESTABLISHED POLICIES AND OPERATIONAL CONTROL PROCEDURES}

PMBOK (2000:189-191) identifies nine factors to be the most appropriate description of established controls policies and procedures. These are summarised as the nine project management knowledge areas, namely: management of project integration scope, time, cost and quality; as well as the facilitation of management attention to human resources, communications, risk and procurement. It follows that an audit of the project should ideally be against the correct use of these control factors, and their relevant success factors. Such an audit should reveal the project control shortcomings.

\section{IDENTIFYING A LIST OF SUCCESS FACTORS}

Before steps for the audit are proposed, a list of the project's proposed success factors needs to be identified.

Rockart (1979:81-92) was one of the first authors that applied a critical success factor approach in identifying information needs, at least in the arena of information systems. Rockart defines critical success factors as the limited number of areas in which results, if they are satisfactory, will ensure successful competitive performance for the organisation.

Esteves \& Pastor (2000) unified lists of researched critical success factors (admittedly with regard to ERP implementations) and developed a critical success factor unified model. The advantage of this model is that it unifies a set of studies related to lists of critical success factors that were identified by other authors. These are then categorised in different perspectives and each critical success factor is then identified and defined.

Dobbins \& Donnely (2004) found that project managers who employed the critical success factor process model learn how to conceive, plan, and implement their programmes in terms of their own unique applicable critical success factors. These success factors are identified by the project manager and not by broader statistical methods.

In principle, the unified lists of critical success factors (CSF's) proposed by Esteves \& Pastor (2000), are by far the simplest means of identifying critical success factors. 
The unified critical success factor model proposed in Figure 1 identifies a matrix of CSF's that cross correlate Strategic \& Tactical factors with Technological \& Organisational perspectives. The organisational perspective is related with concerns like organisational structure and culture. The technological perspective focuses on aspects related to the particular product under consideration and other technical aspects, such as hardware and base software needs. The strategic perspective is related with core competencies and accomplishing the organisation's mission and long-term goals, while the tactical perspective affects the business activities with short-term objectives.

\section{Figure 1: Unified Critical Success Factors Model}

\begin{tabular}{|c|c|c|}
\hline & Strategic & Tactical \\
\hline 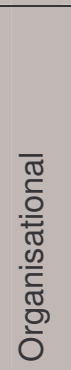 & $\begin{array}{l}\text { - Sustained management support } \\
\text { - } \quad \text { Effective organisational change management } \\
\text { - } \quad \text { Adeod project scope management } \\
\text { - } \quad \text { Comprehensive business process } \\
\text { reengineering } \\
\text { - Adequate project champion role } \\
\text { - User involvement and participation } \\
\text { - Trust between partners }\end{array}$ & $\begin{array}{ll}\text { - } & \text { Dedicated staff and consultants } \\
\text { - } & \text { Strong communication inwards and } \\
& \text { outwards } \\
\text { - } & \text { Formalised project plan/schedule } \\
\text { - } & \text { Adequate training program } \\
\text { - } & \text { Preventative trouble shooting } \\
\text { - } & \text { Empowrowered decision makers }\end{array}$ \\
\hline 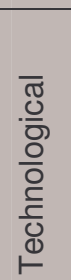 & $\begin{array}{ll}\text { - } & \text { Adequate ERP implementation strategy } \\
\text { - } & \text { Avoid customisation } \\
\text { - } & \text { Adequate ERP version }\end{array}$ & $\begin{array}{l}\text { - } \quad \text { Adequate software configuration } \\
\text { - Legacy systems knowledge }\end{array}$ \\
\hline
\end{tabular}

(Source: Esteves \& Pastor, BIT 2000 conference, Manchester)

\section{PROPOSED STEPS FOR THE AUDIT}

The generic steps for project audit can be summarised as follows:

- Identify a list of suitable success factors, using the knowledge areas of PMl's PMBOK. Recent research by Dobbins \& Donnely (2004) reveals several methods for identification of relevant critical factors.

- Identify an independent body of people to perform the audit against the above identified success factors. These project auditors, if external to the organisation, should identify a random sample of projects to audit. If internal auditors are used, then a process of on-going audits for all current projects could be considered.

- Evaluate the project records, interview representatives of the project teams and review their activities for the use of appropriate controls. The use of these controls can be checked against a table, cross-matrixed with identified success factors (see table 1 as an example).

- Develop a report detailing compliance with controls, policies and procedures as identified in Table 1 , concluding with appropriate corrective action to be taken where necessary. 
Table 1 : Review of Success Factors Against Control Measures

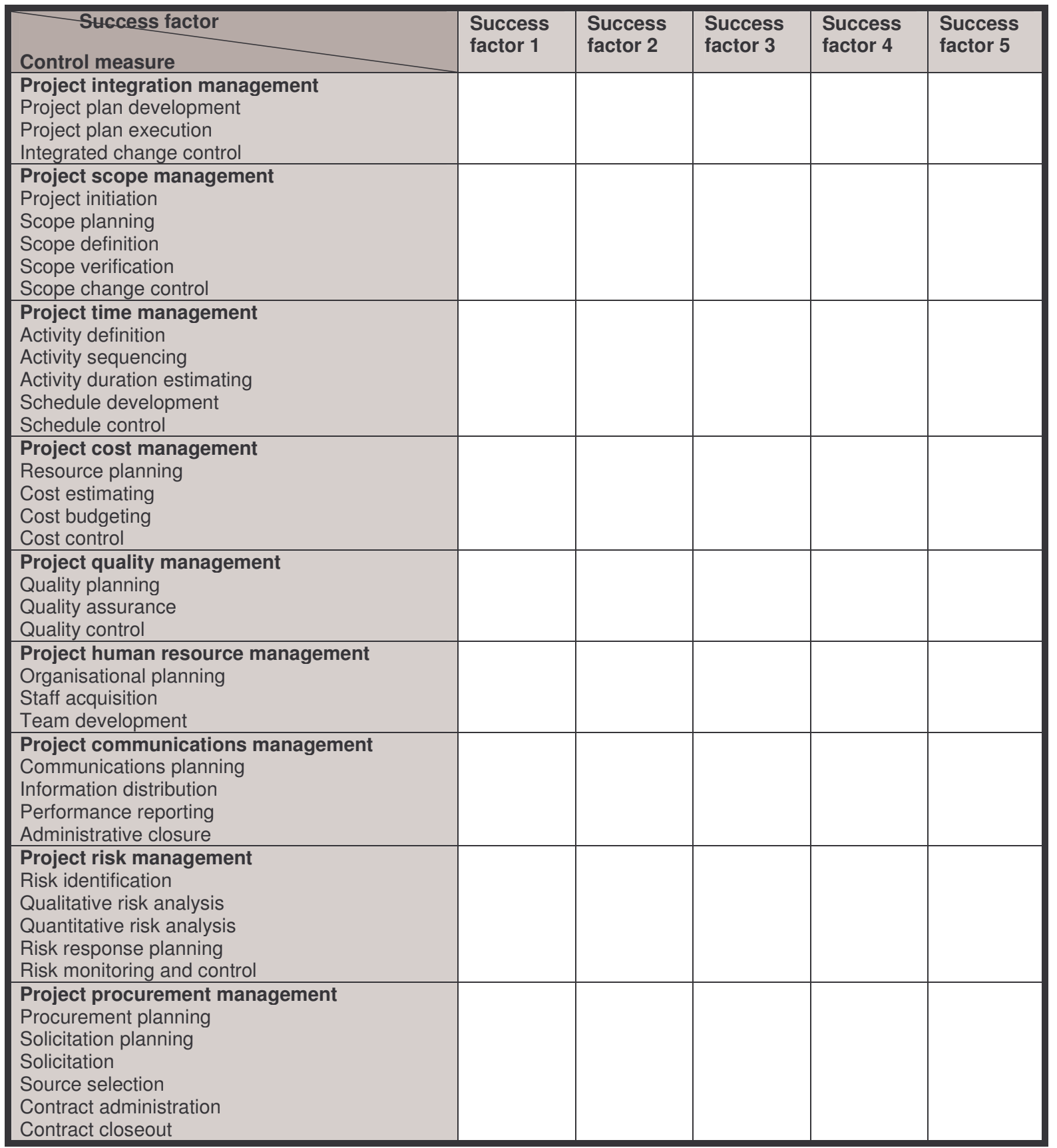

\section{CLOSURE}

In following the process of identifying success factors, appointing an independent audit team, and evaluating an organisation's projects against the control measures most appropriate to its industry, one may well have identified a method for both auditing and grading projects. The identification of appropriate success factors is always subjective. While models have been developed to grade and list 
success factors by order of importance, per industry, others have been developed to generate lists of success factors per project (independent of industry.)

The purpose of this article was to generate some thoughts with regard to the auditing of projects by reviewing its success factors. The proposed matrix could be used in future research and in identifying the success factors of a project.

\section{REFERENCES}

Busby JS. 1999. An assessment of post project reviews. Project Management Journal, 30(3):23-29.

DeFillippi R. 2001. Introduction: project-based learning, reflective practices and learning outcomes. Management Learning, 32(1):5-10.

Dobbins J \& Donnely R. 2004. Critical success factor analysis for technology acquisition program management. London. (PMI Research Conference, 11-14 July; copy of paper in possession of researcher.)

Encyclopaedia Britannica. 2004. Definition of the word Audit. Encyclopaedia Britannica Premium Service [Online] Available from: http://www.Britannica.com/ebc/article?tocld=9011221\&query=audit\&ct= [Downloaded: 2004-11-13].

Federal Highway Administration, U.S. Department of Transportation. 2000. Federal task force on the Boston central artery tunnel project: Review of project oversight and costs [Online] Available from: http://www.fhwa.dot.gov/reports/ tunnel.htm [Downloaded: 2004-12-01].

\section{FHA see Federal Highway Administration}

Esteves J \& Pastor J. 2000. Towards the unification of critical success factors for ERP implementations. Manchester. (10th Annual BIT Conference, 1-2 November; copy of paper in possession of researcher.)

Kerzner H. 1998. Project management: a systems approach to planning scheduling and controlling. $6^{\text {th }}$ ed. New York: Wiley.

Kerzner H. 2000. Applied project management: best practices on implementation. New York : Wiley.

Liu I \& Yetton P. 2004. The contingent effects of project governance mechanisms on project delivery capability and the level of control: Evidence from the Construction and IT Services Industries. London. (PMI Research Conference, 11-14 July; copy of paper in possession of researcher.)

Merriam-Webster Online. 2004. Definition of the word Audit. Merriam-Webster Online Dictionary [Online] Available from: http://www.mew.com/cgi-bin/dictionary?book=Dictionary\&va=audit\&x=11\&y=14 [Downloaded: 2004-11-13].

Morfitt G. 1999. A review of the Fast Ferry project: Governance and risk management: Report 5 [Online] Available from: http://www.bcauditor.com/PUBS /1999-00/report-5/sec-.htm\#auditor\%20general \%20 [Downloaded: 2004-12-05].

Murphy S. 2002. Big dig review to target cost overruns [Online] Available from: http://www.nashtu.us/Reports/Mass5.htm [Downloaded: 2004-12-02].

PMBOK. 2000. A guide to the project management body of knowledge. Project Management institute. Newtown Square: PMI® Global. 
Rockart J. 1979. Chief executives define their own information needs. Harvard Business Review, 57(2):81-93.

Sabherwal R \& King W. 1992. Decision processes for developing strategic applications of information systems: a contingency approach. Decision Sciences, 23:917-943.

Siemens. 1994. ANL Project Management Guidelines. Ver 2. Erlangen: 39.

Turner J \& Keegan A. 2001. Mechanisms of governance in the project-based organization: Roles of the broker and steward. European Management Journal, 19(3):254-267.

Von Zeidtwitz M. 2002. Organisational learning through post project reviews in $R \& D$. R\&D Management, 32(3):255-268.

Websters New World Dictionary. 1977. Webster's New Collegiate Dictionary. Springfield : G\&C Merriam Company.

Williams C. 1977. Auditing the total industrial engineering function. Industrial Management Journal: 910, September-October. 